Lingua Rima: Jurnal Pendidikan Bahasa dan Sastra Indonesia

Vol. 10 No. 1 Januari 2021

http://jurnal.umt.ac.id/index.php//grm

\title{
ANALISIS KESALAHAN BERBAHASA \\ PADA UNGGAHAN PAMFLET MEDIA SOSIAL INSTAGRAM
}

\author{
Indah Septi Eka Ningrum ${ }^{1}$, \\ Universitas Ahmad Dahlan \\ indahekasepti@gmail.com ${ }^{1}$ \\ Ludviana Eka Purnami², \\ Universitas Ahmad Dahlan \\ ludviana1700003061@webmail.uad.ac.id ${ }^{2}$ \\ Asprilia Tika Lestari ${ }^{3}$ \\ Universitas Ahmad Dahlan \\ aspriliatika@gmail.com ${ }^{3}$
}

\begin{abstract}
ABSTRAK
Kajian ini bertujuan untuk mengetahui kesalahan berbahasa pada pamflet yang diunggah oleh media sosial Instagram. Pendekatan penelitian yang digunakan dalam penelitian ini adalah pendekatan kualitatif. Data penelitian ini yaitu wacana pamflet yang diunggah pada media sosial instragam yang berkaitan dengan kesalahan ejaan dan penulisan tanda baca. Sumber data penelitian ini yaitu unggahan pamflet media sosial instagram pada akun instagram @goresanpenatuhan, @kataislamic, @milenialfact, @tajwid_media, @ngajihidup,@sajakjemari, @yowes.suwun, @yowes.suwun. Teknik pengumpulan data dalam penelitian ini yaitu teknik baca dan catat. Teknik analisis data dalam penelitian ini adalah analisis kualitatif deskriptif. Hasil penelitian yaitu terdapat beberapa kesalahan berbahasa dalam media sosial pada Instagram yang terdapat pada berbagai akun, khususnya pada kesalahan huruf, penghilangan huruf, penggunaan kata depan, tanda baca, rangkaian kata, dan penggunaan kata asing.
\end{abstract}

Kata Kunci: kesalahan ejaan, tanda baca, Instagram

\section{A. PENDAHULUAN}

Bahasa mempunyai peran yang amat penting. Bahasa merupakan alat yang berguna dalam setiap aktivitas komunikasi. Bahasa yang berarti sistem, artinya bahasa yang dibentuk oleh sejumlah komponen secara berpola tetap. Sistem bahasa tersebut berupa lambang-lambang bunyi, pada setiap lambang bahasa tersebut melambangkan sesuatu yang disebut konsep atau makna. Karena pada setiap lambang bunyi tersebut memiliki suatu konsep atau makna, maka dapat disimpulkan bahwa suatu ujaran bahasa memiliki makna. Melalui bahasa, kita dapat memahami suatu pandang kita, pemahaman terhadap akan suatu hal, negara kita dan asal usul bangsa, pendidikan, bahkan sifat pada diri kita. Bahasa juga dapat menjadi cermin untuk diri kita Analisis Kesalahan Berbahasa pada Unggahan Pamflet Media Sosial Instagram 


\section{Lingua Rima: Jurnal Pendidikan Bahasa dan Sastra Indonesia \\ Vol. 10 No. 1 Januari 2021 \\ http://jurnal.umt.ac.id/index.php/lgrm}

agar baik sebagai bangsa maupun diri sendiri agar komunikasi berjalan lancar dengan baik penerima dan pengirim bahasa harus menguasai bahasanya.

Banyak dikalangan masyarakat bahkan pelajar yang masih salah dalam menempatkan kata dalam kalimat. Penggunaan kata sering sekali tidak tepat dalam penggunaannya. Kerancuan tersebut pun kerap terjadi higga membingungkan masyarakat dalam penggunaan bahasa baku. Masyarakat atau pelajar sering kali tidak memperhatikan tulisan yang sesuai aturan atau tidaknya. Mereka berfikir paling terpenting tujuan dan maksud tersampaikan. Selain itu ketidak pahaman penggunaan tanda baca, menyebabkan tulisan-tulisan di spanduk, papan nama, selembaran, dan mading. Banyak ditemui kata yang tidak baku dan masih ditemukan kesalahan dalam penulisan tanda baca yang tidak sesuai dengan ejaan yang disempurnakan. Hal tersebut menyebabkan dalam sebuah tulisan kerap tidak sesuai dengan EYD ataupun bahasa baku.

Perkembangan teknologi memaksa masyarakat untuk berkomunikasi secara daring. Masyarakat menjadi senang berkomunikasi secara daring karena dimanapun dan kapanpun mereka dapat melakukan komunikasi. Hal tersebut membuat media sosial menjadi sangat populer. Salah satu media komunikasi yang populer yaitu instagram. Instagram merupakan media yang sering terdapat dengan fitur yang berfokus pada gambar dan video, tidak seperti facebook yang lebih dahulu muncul memiliki fitur lebih bebas dan lebih fleksibel dalam penggunaan. Gambar dan video yang sering di publikasikan oleh pengguna akun di instagram biasanya disertai status (caption) ini yang menjelaskan gambar dan video yang diunggah dalam akun tersebut (Kholifah dan Sabardila, 2020:353).

Kesalahan berbahasa adalah pemakaian bentuk-bentuk tuturan berbagai unit kebahasaan yang meliputi kata, kalimat, paragraf, yang menyimpang dari sistem kaidah bahasa Indonesia baku, serta pemakaian ejaan dan tanda baca yang menyimpang dari sistem ejaan dan tanda baca yang telah ditetapkan sebagaimana dinyatakan dalam buku Ejaan Bahasa Indonesia yang Disempurnakan (Sebayang\&Sofyan, 2019:50). Kesalahan berbahasa terjadi secara sistematis karena belum dikuasainya sistem kaidah bahasa yang bersangkutan. Sedangkan kekeliruan berbahasa terjadi tidak secara sistematis, bukan terjadi karena belum dikuasainya sistem kaidah bahasa yang bersangkutan, melainkan karena kegagalan merealisasikan sistem kaidah bahasa yang sebenarnya sudah dikuasai (Tamara, dkk. 2020:24). Kesalahan berbahasa memiliki tolak ukur yang berupa keberterimaan. Contohnya jika si pembelajar membuat kesalahan, maka tolak 


\section{Lingua Rima: Jurnal Pendidikan Bahasa dan Sastra Indonesia \\ Vol. 10 No. 1 Januari 2021 \\ http://jurnal.umt.ac.id/index.php//grm}

ukur yang bisa dipakai ialah apabila si pembelajar menggunakan kata atau kalimat dengan benar atau salah menurut penutur asli bahasa Indonesia.

Pada bahasa baku, terdapat standar tertentu yang harus terpenuhi dalam penggunaan ragam bahasa. Standar tersebut meliputi penggunaan tata bahasa dan ejaan bahasa Indonesia yang disempurnakan. Tata bahasa Indonesia yang baku meliputi penggunaan kata, dan EYD yang sesuai dengan kaidah baku. Kaidah yang terdapat pada tata bahasa Indonesia yang baku adalah kaidah tata bahasa Indonesia sesuai dengan aturan berbahasa yang ditetapkan oleh Pusat Bahasa Indonesia. Sedangkan, kaidah ejaan bahasa Indonesia yang baku adalah kaidah ejaan bahasa Indonesia yang disempurnakan. Penelitian ini menganalisis kesalahan berbahasa pada pamflet yang diunggah oleh media sosial Instagram.

\section{METODE PENELITIAN}

Pendekatan penelitian yang digunakan dalam penelitian ini adalah pendekatan kualitatif. Data penelitian ini yaitu wacana pamflet yang diunggah pada media sosial instragam yang berkaitan dengan kesalahan ejaan dan penulisan tanda baca. Sumber data penelitian ini yaitu unggahan pamflet media sosial instagram pada akun instagram @goresanpenatuhan, @kataislamic, @milenialfact, @tajwid_media, @ngajihidup, @ sajakjemari, @pns_lunch_time,

$@$ yowes.suwun, @yowes.suwun. Teknik pengumpulan data dalam penelitian ini yaitu teknik baca dan catat. Peneliti membaca unggahan pamflet di akun instagram kemudian mencatat katakata yang terdapat kesalahan ejaan dan tanda baca. Teknik analisis data dalam penelitian ini adalah analisis kualitatif deskriptif. Analasis kualitatif penelitian ini dengan tahapan menemukan kesalahan bahasa yang digunakan dalam bahasa Indonesia, kemudian mengklasifikasikan data sesuai dengan bentuk kesalahan penulisan dalam kesalahan bahasa Indonesia dikaitkan dengan konteks yang mengikutinya.

\section{HASIL PENELITIAN DAN PEMBAHASAN}

Kesalahan ejaan merupakan salah satu dalam bidang kesalahan bahasa. Penelitian ini akan mengkaji kesalahan ejaan yang meliputi kesalahan penggunaan tulisan, kesalahan struktur tata bahasa, pemakaian diksi, dan pemakaian bahasa asing. Pada penggunaan tanda baca, terdapat beberapa kesalahan yang terdapat pada kutipan berikut.

(1) Ada do'a yang kulangitkan hari ini tentang kamu. Semoga Sehat dan Bahagia selalu. Jaga dirimu, tidak sekedar hati-hati tapi jaga hati. ("do'a, sekedar" postingan @ goresanpenatuhan ) 


\section{Lingua Rima: Jurnal Pendidikan Bahasa dan Sastra Indonesia \\ Vol. 10 No. 1 Januari 2021 \\ http://jurnal.umt.ac.id/index.php/lgrm}

Penggunaan kata do'a dan sekedar yang benar terjadi kesalahan dalam tanda baca tanda petik. Pembenaran pada kutipan tersebut yaitu adalah doa dan sekadar. Selain itu, terdapat kesalahan tanda baca pada kutipan berikut:

(2) Pertama karena aku sedang berfikir. Kedua karena aku coba memahami, ketiga karna aku sedang tidak baik-baik saja. ("berfikir, karna” postingan@kataislamic)

Penggunaan kata berfikir dan karna yang benar terjadi kesalahan dalam penggunaan huruf dan penghilangan huruf. Pembenaran pada kutipan tersebut yaitu adalah berpikir dan karena. Selain itu, terdapat kesalahan tanda baca pada kutipan berikut:

adalah berpikir dan karena.

(3) Jika mereka berdiri dibelakangmu, Lindungi mereka. Jika mereka berdiri disampingmu, Hormati disampingmu, Hormati mereka. Jika mereka berdiri melawanmu, Kalahkan mereka. (“dibelakangmu, disampingmu” postingan @ milenialfact)

Kata yang benar dari dibelakangmu dan disampingmu yaitu dipisah karena merupakan kata kerja pasif, yang benar di belakangmu dan di sampingmu. Selain itu, penggunaan huruf kapital di tengah kalimat, yaitu Lindungi. Penulisan yang benar setelah tanda koma tidak menggunakan menggunakan huruf kapital pada awal kalimat.

(4) Semapan apapun pasanganmu maka akan percuma jika agama tidak dijadikan yang utama, sebab lelaki yang paham dengan agama dia bukan hanya akan memikirkan kebahagianmu didunia saja namun bagaimana caranya bisa bahagia di syurga. (“apapun, didunia, di syurga” postingan@tajwid_media)

Kutipan di atas terdapat kesalahan pemenggalan kata apapun dan didunia. Kata yang benar dari apapun dan didunia yaitu dipisah menjadi apa pun dan di dunia. Selain itu, penggunaan kata syurga merupakan kesalahan berbahasa karena yang benar adalah surga.

(5) "Cintailah orang sholeh. Sehingga kita akan dikumpulkan dengan orang sholeh, sekalipun amal kita tidak seperti mereka"-KH. Ahmad Zuhdianoor. ("sholeh" postingan @ngajihidup)

Kutipan di atas, terdapat kesalahan kata sholeh. Penggunaan pada kata sholeh yang benar adalah saleh. Selain itu, terdapat kesalahan pemenggalan kata pada kutipan berikut.

(6) Selagi ingin menangis, menangis lah sepuasnya hingga air mata mu itu tidak menetes lagi di pipimu lalu bercerita lah sepuas nya dengan orang yang kamu percaya dan ingat sehabis ini kamu jangan menangis lagi karna waktu nya kamu harus bahagia. ("menangis lah mata mu bercerita lah sepuas nya karna waktu nya" postingan @ sajakjemari) 


\section{Lingua Rima: Jurnal Pendidikan Bahasa dan Sastra Indonesia \\ Vol. 10 No. 1 Januari 2021 \\ http://jurnal.umt.ac.id/index.php/lgrm}

Penggunaan pada kata menangis lah dan bercerita lah merupakan kesalahan berbahasa. Penulisan partikel 'lah' ditulis serangkai dengan kata yang mendahuluinya. Maka, menjadi menangislah dan berceritalah. Pada kata mata mu, sepuas nya, dan waktu nya penulisan kata ganti 'mu' dan 'nya' ditulis serangkai dengan kata mendahuluinya. Maka, pembenarannya matamu, sepuasnya, dan waktunya. Selain itu, pada kata karna mengalami kesalahan. Penulisan yang benar adalah karena.

(7) Mungkin awak dewe gor di takdirke ketemu ora bersatu.( "Awak dewe gor di takdirke, ora" postingan @yowes.suwun)

Pada kutipan tersebut, terdapat kesalahan berbahas yaitu penggunaan bahasa asing. Kata awak dewe gor di takdirke dan ora seharusnya ditulis dengan kita hanya ditakdirkan dan tidak. Selain itu, penggunaan kesalahan kata asing terdapat pada kutipan berikut.

(8) Tuhan ;

Jika perasaan ini salah arah, tolong shareloc. (“shareloc” Postingan @yowes.suwun)

Kutipan tersebut terdapat kesalahan berbahasa. Pada kata shareloc yang dimaksud adalah bagian lokasi. Penulisan yang benar seharusnya ditulis menjadi share location.

\section{E. SIMPULAN}

Berdasarkan hasil pembahasan di atas, maka penulis menyimpulkan bahwa terdapat beberapa kesalahan berbahasa dalam media sosial pada Instagram yang terdapat pada berbagai akun, khususnya pada kesalahan huruf, penghilangan huruf, penggunaan kata depan, tanda baca, rangkaian kata, dan penggunaan kata asing. Kesalahan berbahasa memisahkan antara kesalahan berbahasa atau bisa disebut error dengan kekeliruan berbahasa atau bisa disebut miskate. Arti dari kesalahan berbahasa ialah penyimpangan yang sifatnya sitematis serta konsisten, sedangkan kekeliruan merupakan penyimpangan yang tidak sistematis pada perilaku bahasa.

\section{F. DAFTAR PUSTAKA}

Kholifah, U. \& Sabardila, A. 2020. Analisis Kesalahan Gaya Bahasa pada Sosial Media Instagram dalam Caption dan Komentar. Nusa. Vol. 15 No. 3 PP 352-365

Sebayang, S. K. H. \& Sofyan, A. S. 2019. Analisis Kesalahan Berbahasa pada Sosial Media Instagram dalam Postingan, Komentar, dan Cerita Singkat. Jurnal Serunai Bahasa Indonesia Vol.16, No.1 PP 49-57

Tamara, Dkk. 2020. Analisis Kesalahan Penggunaan Ejaan dan Tanda Baca pada Media Sosial Resmi Universitas Ahmad Dahlan. Jurnal Parafrasa: Bahasa, Sastra, dan Pengajaran Vol. 2 No.1 Hal. 22-29 